PNL-7173

UC-920

$15 \%$

\title{
Peak Load Management: Potential Options
}
J. E. Englin
R. W. Schultz
J. G. De Steese
M. A. Kellogg

October 1989

Prepared for the

Bonneville Power Administration

under a Related Services Agreement

with the U.S. Department of Energy

under Contract DE-AC06-76RLO 1830

Pacific Northwest Laboratory

Operated for the U.S. Department of Energy

by Battelle Memorial Institute 


\title{
DISCLAIMER
}

This program was prepared as an account of work sponsored by an agency of the United States Covernment. Neither the United States Covernment nor any agency thereof, nor Battelle Memorial Institute, nor any or their employees, makes any warranty, expressed or implied, or assumes any legal liability of responsibility for the accuracy, completeness, or usefulness of any information, apparatus, product, or process disclosed, or represents that its use would not infringe privately owned rights. Reference herein to any specific commercial product, process, or service by trade name, trademark, manufacturer, or otherwise, does not necessarily constitute or imply its endorsement, recommendation, or favoring by the United States Government of any agency thereof, or Battelle Mernorial Institute. The views and opinions of authors expressed herein do not necessarily state or refiect those of the United States Government or any agency thereof.

\author{
PACIFIC NORTHWEST LABORATORY \\ operated by \\ BATTELLE MEMORIAL INSTITUTE \\ for the \\ UNITED STATES DEPARTMENT OF ENERGY \\ under Contract DE-ACO6-76RLO 1830
}

Printed in the United States of America

Available to DOE and DOE contractors from the

Office of Scientific and Technical Information, P.O. Box 62, Oak Ridge, TN 37831;

prices available from (615) 576-8401. FTS 626-8401.

Avalable to the public from the National Technical Information Service,

U.5. Department of Commerce, 5285 Port Royal Rd., Springfield, VA 22161.

NTIS Price Codes, Microfiche A01

Printed Copy

\begin{tabular}{|c|c|}
\hline Pages & $\begin{array}{l}\text { Price } \\
\text { Codes }\end{array}$ \\
\hline $001-025$ & $\mathrm{~A} 02$ \\
\hline $026-050$ & $\mathrm{~A} 03$ \\
\hline $057-075$ & $\mathrm{~A} 04$ \\
\hline $076-100$ & A05 \\
\hline $101-125$ & $\mathrm{~A} 06$ \\
\hline $126-150$ & $\mathrm{~A} 07$ \\
\hline $157-175$ & $\mathrm{~A} 08$ \\
\hline $776-200$ & $\mathrm{~A} 09$ \\
\hline $201-225$ & A 10 \\
\hline $226-250$ & A 11 \\
\hline $251-275$ & A12 \\
\hline $276-300$ & A 13 \\
\hline
\end{tabular}


PNL-7173

UC -920

PEAK LOAD MANAGEMENT:

POTENTIAL OPTIONS

J. E. Englin, Project Manager

J. G. De Steese

R. W. Schultz

M. A. Kellogg

October 1989

Prepared for

the Bonneville Power Administration under a Related Services Agreement with the U.S. Department of Energy under Contract DE-ACO6-76RLO 1830

Pacific Northwest Laboratory Richland, Washington 99352 
.

. 


\section{ABSTRACT}

This report reviews options that may be alternatives to transmission construction (ATT) applicable both generally and at specific locations in the service area of the Bonneville Power Administration (BPA). Some of these options have potential as specific alternatives to the Shelton-Fairmount 230kV Reinforcement Project, which is the focus of this study. A listing of 31 peak load management (PLM) options is included. Estimated costs and normalized hourly load shapes, corresponding to the respective base load and controlled load cases, are considered for 15 of the above options. A surmary page is presented for each of these options, grouped with respect to its applicability in the residential, conmercial, industrial, and agricultural sectors. The report contains conments on PLM measures for which load shape management characteristics are not yet available. These conments address the potential relevance of the options and the possible difficulty that may be encountered in characterizing their value should they be of interest in this investigation. The report also identifies options that could improve the efficiency of the three customer utility distribution systems supplied by the Shelton-Fairmount Reinforcement Project. Potential cogeneration options in the 0lympic Peninsula are also discussed. These discussions focus on the options that appear to be most promising on the 0lympic Peninsula. Finally, a short list of options is recommended for investigation in the next phase of this study. 
' 
CONTENTS

ABSTRACT .............................

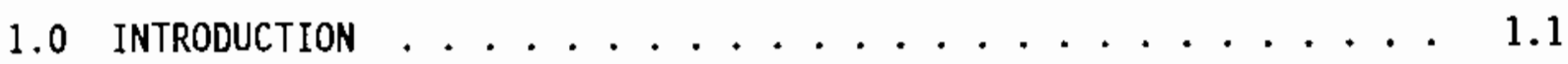

1.1 ALTERNATIVES TO TRANSMISSION OPTIONS .......... 1.1

1.2 HOURLY BASE LOAD AND CONTROLLED LOAD CURVES . . . . . . 1.1

1.3 SELECTED OPTIONS WITH EXISTING HOURLY LOAD DATA $\ldots \ldots . . \quad 1.3$

1.4 GENERAL COMMENTS ON SUMMARY PAGE INFORMATION . . . . . 1.3

1.5 BALANCE OF REPORT . . . . . . . . . . . . 1.5

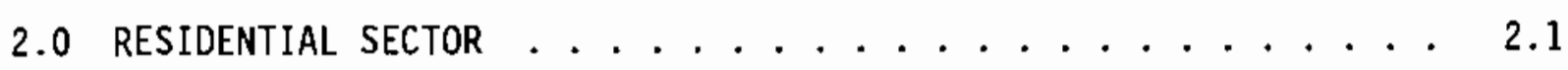

2.1 RESIDENTIAL WEATHERIZATION PROGRAM .............. 2.2

2.2 RESIDENTIAL SUPER RETROFIT PROGRAM . . . . . . . . 2.3

2.3 CURRENTLY PROPOSED RESIDENTIAL MODEL CONSERVATION

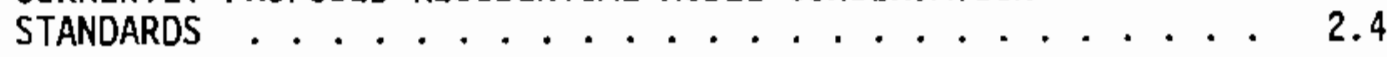

2.4 ENHANCED RESIDENTIAL MOOEL CONSERVATION STANDARDS . . . $\quad 2.5$

2.5 RESIDENTIAL CERAMIC HEAT STORAGE - PRIMARY SYSTEM . . . . 2.6

2.6 RESIDENTIAL CERAMIC HEAT STORAGE - BACK-UP SYSTEM $\ldots \ldots .2 .7$

2.7 RESIDENTIAL DIRECT SPACE HEAT CONTROL . . . . . . . 2.8

2.8 RESIDENTIAL GAS BACK-UP PROGRAM FOR ELECTRIC HEAT

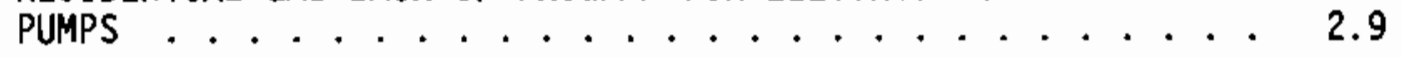

2.9 RESIDENTIAL DIRECT WATER HEATER CONTROL $\ldots \ldots . . . . .2 .10$

2.10 RESIDENTIAL DUAL WATER HEATER CONTROL ......... 2.11

2. II RESIDENTIAL SMART WHOLE HOUSE LOAD LIMITERS . . . . . . . 2.12

3.0 COMMERCIAL SECTOR . . . . . . . . . . . . . . 3.1

3.1 COMMERCIAL LIGHTING - LIGHT REPLACEMENT PROGRAM . . . . 3.3

3.2 COMMERCIAL LIGHTING - REPLACEMENT OF BALLASTS AND LAMPS . . 3.5

4.0 AGRICULTURAL IRRIGATION EFFICIENCY PROGRAM $\ldots \ldots \ldots . \ldots . \ldots$ 
5.0 INDUSTRIAL MOTOR CAPACITANCE .................... 5.1

6.0 LOAD MANAGEMENT OPTIONS LACKING DATA . . . . . . . . . 6.1

7.0 EFFICIENCY IMPROVEMENT OF CUSTOMER UTILITY SYSTEMS $\ldots \ldots \ldots$

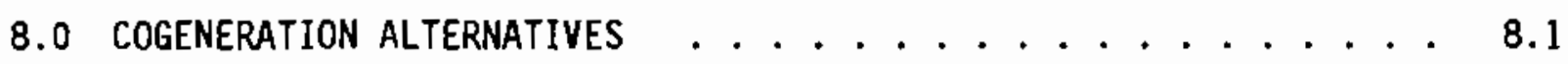

9.0 INTERIM RECOMMENDATIONS . . . . . . . . . . . . . 9.1

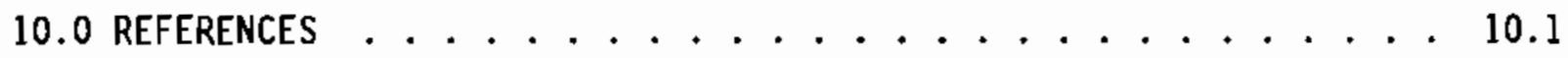




\section{$\underline{\text { TABLES }}$}

1.1 Conservation and Load Managenent Options ......... 1.2

1.2 Select List of Conservation and Load Management Options . . . . 1.4

2.1 Residential Weatherization Program Hourly Loads . . . . . . . 2.2

2.2 Residential Super Retrofit Program Hourly Loads . . . . . . . 2.3

2.3 Currently Proposed Residential MCS Hourly Loads . . . . . . . . 2.4

2.4 Enhanced Residential MCS Hourly Loads . . . . . . . . . . . 2.5

2.5 Residential Ceramic Heat Storage Primary System Hourly Loads . . 2.6

2.6 Residential Ceramic Heat Storage Back-up System Hourly Loads . . 2.7

2.7 Residential Direct Space Heat Control Hourly Loads . . . . . . 2.8

2.8 Residential Gas Back-up for an Electric Heat Pump Hourly

2.9 Residential Direct Water Heater Control Hourly Loads . . . . . 2.10

2.10 Residential Dual Water Heater Control Hourly Loads . . . . . . 2.11

2.11 Residential Smart Whole House Load Limiters . . . . . . . . 2.12

3.I Commercial Lighting - Office Buildings Light Replacement Program ................. . . 3.3

3.2 Commercial Lighting - Dry-Goods/Retail Stores Light Replacement Progran . . . . . . . . . . . . . . 3.4

3.3 Commercial Lighting - Restaurants Light Replacement Program . . . 3.4

3.4 Commercial Lighting - Office Buildings Replacement of Ballasts and Lamps................... . . 3.6

3.5 Commercial Lighting - Dry-Goods/Retail Stores Replacement of Ballasts and Lamps . . . . . . . . . . . . . . . 3.6

3.6 Commercial Lighting - Restaurants Replacement of Ballasts and Lamps . . . . . . . . . . . . . . . . . . . . . 3.7

4.1 Agricultural Irrigation - Irrigation Efficiency Program . . . . . 4.1

5.1 Industrial Motor Capacitance - Chemical, Metals and Lumber . . . 5.1 
5.2 Industrial Motor Capacitance - Tota $\ldots . . . . . . .5 .2$

7.1 Customer Utility Sales ................ 7.1

8.1 Selected Technically Feasible Quantities of Industrial

Cogeneration ...................... 8.1 


\subsection{INTRODUCTION}

This is a report on options that may be alternatives to transmission construction (ATT) applicable both generally and at specific locations in the service area of the Bonnevitle Power Administration (BPA). This document contains the following:

1. a 7 ist of 31 peak load management (PLM) options that may have potential as specific alternatives to the Shel ton-Faimount $230-\mathrm{kV}$ reinforcement project described in the BPA Transmission System Facilities, Ten Year Development Plan for the period 1988-1997

2. summaries of 15 of the above measures showing estimated costs and normalized hourly load shapes for the respective base-load and controlled-load cases

3. comments on PLM measures for which load shape management characteristics are not yet available

4. a list, in order of potential cost effectiveness, of options that could improve the efficiency of customer utility distribution systems in the affected area

5. the findings of an examination of software packages for potential al ternatives to the CILOC (Conservation-In-Lieu-of-Construction) Code

6. a short 1 ist of recommended options that are the primary choices for further investigation.

\section{I PEAK LOAD MANAGEMENT OPTIONS}

Alternatives to transmission options are considered to be any conservation or Toad-management measure together with distribution system improvements that can, in some optimal combination, defer or eliminate the need for additional transmission capacity in a given service area. Table 1.1 lists 31 generic nongenerating PLM measures that should be reviewed for potential value in this study.

\subsection{HOURLY BASE LOAD AND CONTROLLED LOAD CURVES}

The ATT model known as the CILOC Code, developed previously by The Pacific Northwest Laboratory (PNL) for BPA (Engl in et al. 1987), will be used in this study. The model estimates the potential of specific conservation 
IABLE 1.1. Conservation and Load Management Options

1. Residential Weatherization Program (RESWX)

2. Super Retrofit Program (similar to Hood River)

3. Currently Proposed Residential Model Conservation Standards (MCS)

4. Enhanced Residential MCS

5. Commercial Light Replacement Program

6. Commercial Ballast or Fixture Replacement Program

7. Commercial EMS Program

8. Currently Proposed Commercial MCS

9. Enhanced Commercial MCS

10. Self-financed Conmercial Audits and Measures Installation

11. Commercial Time-of-Day (TOD) Pricing

12. Industrial TOD Pricing

13. Residential TOD Pricing

14. Water Heater Controls

15. Dual Water Heater Control

16. Space Heat Control

17. Whole-house (Smart) Load Limiters

18. Residential Heat Storage

19. Heat Pump Program

20. Commercial Heat Storage

21. Commercial Cool Storage

22. Street Lighting Retrofit

23. Institutional Building Weatherization Program

24. Industriat Motor Replacement

25. Industrial Motor Speed Control

26. Capacitors for Industrial Motors

27. Irrigation Motor Control

28. Irrigation Efficiency Program Lateral Displacement

29. Irrigation Efficiency Program Pump Efficiency Improvement

30. Irrigation Efficiency Program Low Pressure

31. Irrigation Efficiency Program Drip Program 
and/or load management (C\&LM) measures to reduce or delay the need for new transmission and distribution (T\&D) construction required when load growth occurs in part of the system. To evaluate whether each C\&LM measure could be a viable ATT option, the model requires, as input, hourly end-use load curves that are representative of each end use. These are referred to as the baseload curves for the end-use load in question. The model also requires input of hourly end-use load curves that represent the effect of applying the C\&LM measure(s) under consideration. These curves are referred to as controlledload curves.

\subsection{SELECTED OPTIONS WITH EXISTING HOURLY LOAD DATA}

Base-load and controlled-load curves were developed for 15 of the measures shown in Table 1.1 to facilitate studies in the Customer System Efficiency Improvement (CSEI) Project conducted previously by PNL for BPA. Table 1.2 lists these options and compares their peak reduction ratio; initial cost and annual cost per end-use application.

A summary page, including tabulated load shape data, is presented for each of the selected 15 options in Chapters 2.0 through 5.0 , grouped with respect to their applicability in the residential, commercial, industrial, and agricultural sectors. In the CSEI study these measures were selected from the list of 31 alternatives to represent the most potentially effective C\&LM measures. It would be advisable to review this selection with regard to the needs of the present project. Any measure not among the short 1 ist of 15 options would need to be researched to the same level of detail before it couid provide useful input to the ATT model (see further comments in Chapter 6.0).

\subsection{GENERAL COMMENTS ON SUMMARY PAGE INFORMATION}

The base-load curves, shown for each of the selected 15 options, represent hourly end-use electrical loads for a typical, nonholiday weekday in the peak use season. The controlled-load curves were derived from corresponding base-load curves by determining the impact each C\&LM option had on its respective end-use load curve. Included in the presentation of each C\&LM 
IABLE 1.2. Select List of Conservation and Load Management Options

\begin{tabular}{|c|c|c|c|}
\hline C\&L4 Option & $\begin{array}{c}\text { Peak Redyction } \\
\text { Ratio(a) } \\
\text { (Controlled/ } \\
\text { Bage Load) } \\
\end{array}$ & $\begin{array}{c}\text { Initel } \\
\text { Cost }(\$)\end{array}$ & $\begin{array}{c}\text { Yearly } \\
\text { Cost (\$) }\end{array}$ \\
\hline Residential Weatherization Progran & 0.7 & $0^{(b)} /$ site & $o^{(b)} /$ site \\
\hline Super Retrofit Progrem (similar to the Hood River Progrea) & 0.71 & $59 /$ site & $0 /$ site \\
\hline Currently Proposed Residential MCS & 0.72 & $0^{(b)} /$ site & $o^{(b)} /$ site \\
\hline Enhanced Residential MCS & 0.57 & $1,715 /$ site & $0 /$ site \\
\hline Primary Residential Heat storage & 0.0 & $2450 /$ site & $0 /$ site \\
\hline Backup Residential Heat Storage & 0.0 & $1400 /$ site & 0/site \\
\hline Residential Space Heat Control & 0.75 & $150 /$ site & $0.40 /$ site \\
\hline Residential Ges Beck-up Program for Electric Heat Punps & 0.0 & $1500 /$ site & $0 /$ site \\
\hline Residential Water Heater Control & 0.0 & $150 /$ site & $0.40 /$ site \\
\hline Residential Dual Water Heater Control & 0.0 & $400 /$ site & $0.40 /$ site \\
\hline Residential Whole-house (Smert) Load Limiters & 0.8 & $2500 /$ site & $0 /$ site \\
\hline Comercial Light Replacement Program & 0.85 & $0.89^{(c)} /$ butb & 0/buslb \\
\hline Comarcial Lighting: Replacement of Ballasts and Lamps & 0.65 & $14^{(d)} /$ fixture & 0/fixture \\
\hline Agricuttural Irrigation Efficiency Program & 0.65 & $0^{(b)} /$ site & $\sigma^{(b)} /$ site \\
\hline Capacitors for Intestrial Notors & 0.82 & $13.3 / \mathrm{hp}$ & $0 / \mathrm{hp}$ \\
\hline
\end{tabular}

(a) At hour of original peak.

(b) No additional cost since the program is now in effect

(t) Additional cost when a burned-out 40 wett buib is replaced. Cost of a new efficient bulb is $\$ 2.64$ versus $\$ 1.75$ for a standard bulb.

(d) Additional cost when a failed ballast for a 40 watt bulb is replaced. Cost of an energy efficient ballast is $\$ 28.00$ versus $\$ \$ 4.00$ for a standard ballast.

option is the summary description of the option, specific hourly base and controlled-load information, and cost of the option.

The load curves and C\&LM options were evaluated in two steps. The first step was to develop base-load curves representing the hourly load variation of a typical end use. The second step was to derive similar controlled-load curves for each end use, adjusted appropriately to account for the effect of a particular C\&LM option. 
For consistency in comparison across C\&LM measures, all hourly base-load . values are normalized to the maximum hourly load value such that the load at the peak hour appears as 1.0 throughout this report. To convert to the actual kW load for any hour, the normalized load is multiplied by a conversion factor equal to the maximum hourly $\mathrm{kW}$ load at the peak hour. Conversion factors are reported for each C\&LM option analyzed so that the actual kW load for any hour can be easily obtained.

Information relating to the load changing effect of load management options was obtained from several sources. Specific information sources and/or assumptions are documented independently for each of the specific options. However, it is important to note that the 1986 Northwest Conservation and Electric Power Plan (NWPPC 1986) is a principal source of such information.

\subsection{BALANCE OF REPORT}

Chapter 6.0 contains comments on the measures in Table 1.1 that are not among the 16 selected options. These comments address the potential applicability of these options and the possible difficulty that may be encountered in characterizing their value should they be of interest in this investigation.

Chapter 7.0 contains a 1 ist and comments on options that could improve the efficiency of the three customer utility distribution systems supplied by the Shelton-Fairmount reinforcement project. While these options are not expected to contribute a large ATT value, they represent options that should be reviewed to determine their conservation resource value and cost effectiveness in comparison with load-management options.

Chapter 8.0 presents a brief overview of potential cogeneration options. These focus on the options that appear to be most promising on the 0lympic Peninsula. One aspect of the overview is that there appears to be a considerable potential for cogeneration in the area. The precise areas where cogeneration is possible ranges from wood products plants to hotels and motels. 
Chapter 9.0 contains current recommendations including a short list of recommended options that are the primary, but not necessarily, exclusive, choices for further investigations in this study. In addition, a summary of findings with regard to software tools is included in chapter 9.0. 


\subsection{RESIDENTIAL SECTOR}

The primary source of residential sector data for the generation of base-case end-use load curves was the hourly end-use database produced by the Pacific Power and Light Company (PP\&L). The database was developed by the PP\&L Albany-Bend Project in which end uses in approximately 60 residences in Albany and Bend, Oregon were metered from April 1983 to April 1984. (a) Since most of BPA service area has winter-season peak-power use during weekdays, data for a January 1984 nonholiday weekday were used to develop residential base-load curves. Hourly load models were fitted using regression techniques for three different types of space heating equipment, water heating, and other electricity uses for Albany and for Bend separately. The A]bany-Bend areas were analyzed separately (disaggregated) to allow for eastern Oregon (i.e., Bend) and western Oregon (i.e., Albany) regional differences in weather patterns and typical energy use. The fitted models were used with regional average hourly January 1984 temperature data to obtain a set of predicted base-case end-use load curves. Finally, eastern and western Oregon predicted base-case load curves were weighted ${ }^{(b)}$ and summed to obtain a set of weighted average end-use load curves typical of those in the BPA service area. Thus, given average hourly temperatures for January 1984, a specific residential hourly base-case load value represents the regionally weighted average predicted hourly load.

The development of the heat pump load curve was the one exception to the above methodology. The Albany and Bend heat pump load curves were developed by averaging (i.e., not predicting via a regression model) actual January 1984 weekday loads of customers with heat pumps. Regional weights were then applied to those loads to obtain the base-case weighted-average load curve.

(a) Data from the BPA End-Use Load Conservation Assessment Program (ELCAP) were used in this analysis for the load shapes in the commercial sector.

(b) Weights were calculated at PNL by taking the number of residential customers in nongenerating utilities east and west of the Cascade Mountains and dividing each by the total number of residential customers. The eastern weight $(0.4471)$ was applied to the Bend results and the western weight $(0.5529)$ was applied to the Albany resuits. 


\subsection{RESIDENTIAL WEATHERIZATION PROGRAM}

End use targeted: Space heating in existing residential buildings Description: Upgrade of weatherization measures

Base load data source: PP\&L Project for central electric furnaces

Controlled load data source: NWPPC (1986)

Savings: $45 \% \times$ average hour load

Peak hour load: $3.374 \mathrm{~kW}$

Cost: Implementation of this program would consist of concentrating the promotion of the current weatherization program in areas where its load control value is most effective in contributing to ATT objectives. The intensified effort in the load control area would be balanced with a decrease in effort in other areas. Therefore, the initial costs of this program are assumed to be zero. Weatherization programs do not incur recurring annual costs.

IABLE 2.1. Residential Weatherization Program Hourly Loads(a)

\begin{tabular}{|c|c|c|c|c|c|}
\hline Hour & $\begin{array}{l}\text { Base Load } \\
\frac{(k W)}{}\end{array}$ & $\begin{array}{l}\text { Controlled } \\
\text { Load (kW) }\end{array}$ & Hour & $\begin{array}{l}\text { Base Load } \\
\begin{array}{l}(k W) \\
\end{array}\end{array}$ & $\begin{array}{l}\text { Control led } \\
\text { Load (kW) }\end{array}$ \\
\hline $\begin{array}{r}1 \\
2 \\
3 \\
4 \\
5 \\
6 \\
7 \\
8 \\
9 \\
10 \\
11 \\
12\end{array}$ & $\begin{array}{l}0.431 \\
0.423 \\
0.444 \\
0.468 \\
0.507 \\
0.570 \\
1.822 \\
1.0 \\
0.899 \\
0.814 \\
0.759 \\
0.708\end{array}$ & $\begin{array}{l}0.237 \\
0.233 \\
0.244 \\
0.257 \\
0.279 \\
0.314 \\
0.452 \\
0.550 \\
0.494 \\
0.448 \\
0.417 \\
0.389\end{array}$ & $\begin{array}{l}13 \\
14 \\
15 \\
16 \\
17 \\
18 \\
19 \\
20 \\
21 \\
22 \\
23 \\
24\end{array}$ & $\begin{array}{l}0.669 \\
0.617 \\
0.562 \\
0.568 \\
0.635 \\
0.714 \\
0.684 \\
0.626 \\
0.642 \\
0.605 \\
0.487 \\
0.424\end{array}$ & $\begin{array}{l}0.369 \\
0.339 \\
0.309 \\
0.312 \\
0.349 \\
0.393 \\
0.376 \\
0.344 \\
0.353 \\
0.333 \\
0.268 \\
0.233\end{array}$ \\
\hline
\end{tabular}

(a) Normalized to peak hour load; conversion factor $=3.374 \mathrm{~kW}$. 


\subsection{RESIDENTIAL SUPER RETROFIT PROGRAM}

End use targeted: Space heating in existing residential buildings

Description: Upgrade of weatherization measures with the installation of a11 retrofit weatherization measures identified by the NWPPC (1986, page 5-8).

Base load data source: PP\&L Project for central electric furnaces

Controlled load data source: NWPPC (1986)

Savings: $47 \% \times$ average hour load

Peak hour load: $3.374 \mathrm{~kW}$

Cost: Cost of implementing the program beyond current programs is $\$ 79$ per household (NWPPC 1986, Table 5-10).

IABLE 2.2. Residential Super Retrofit Program Hourly Loads(a)

\begin{tabular}{|c|c|c|c|c|c|}
\hline Hour & $\begin{array}{l}\text { Base Load } \\
\frac{(k-k)}{}\end{array}$ & $\begin{array}{l}\text { Control led } \\
\text { Load (kil) }\end{array}$ & Hour & $\begin{array}{l}\text { Base Load } \\
(\mathbf{k W})\end{array}$ & $\begin{array}{l}\text { Controlled } \\
\text { Load (kw) }\end{array}$ \\
\hline $\begin{array}{r}1 \\
2 \\
3 \\
4 \\
5 \\
6 \\
7 \\
8 \\
9 \\
10 \\
11 \\
12\end{array}$ & $\begin{array}{l}0.431 \\
0.423 \\
0.444 \\
0.468 \\
0.507 \\
0.570 \\
0.822 \\
1.0 \\
0.899 \\
0.814 \\
0.759 \\
0.708\end{array}$ & $\begin{array}{l}0.228 \\
0.224 \\
0.235 \\
0.248 \\
0.269 \\
0.302 \\
0.436 \\
0.530 \\
0.476 \\
0.431 \\
0.402 \\
0.375\end{array}$ & $\begin{array}{l}13 \\
14 \\
15 \\
16 \\
17 \\
18 \\
19 \\
20 \\
21 \\
22 \\
23 \\
24\end{array}$ & $\begin{array}{l}0.669 \\
0.617 \\
0.562 \\
0.568 \\
0.635 \\
0.714 \\
0.684 \\
0.626 \\
0.642 \\
0.605 \\
0.487 \\
0.424\end{array}$ & $\begin{array}{l}0.355 \\
0.327 \\
0.298 \\
0.301 \\
0.337 \\
0.378 \\
0.363 \\
0.332 \\
0.340 \\
0.321 \\
0.258 \\
0.225\end{array}$ \\
\hline
\end{tabular}

(a) Normalized to peak hour load; conversion factor $=3.374 \mathrm{~kW}$. 


\subsection{CURRENTLY PROPOSED RESIDENTIAL MODEL CONSERVATION STANDARDS}

End use targeted: Space heating in new residential buildings

Description: Upgrade of weatherization of new residential buildings with the installation of a set of weatherization measures as identified by the NWPPC (1986, pages 5-11 through 5-26)

Base load data source: PP\&L Project for central electric furnaces

Controlled Joad data source: Office of Conservation, BPA

Savings: $45 \% \times$ average hour load

Peak hour Joad: $3.586 \mathrm{kH}$

Cost: Implementation of this program would consist of concentrating the promotion of the current weatherization program in areas where its load control value is most effective in contributing to ATT objectives. The intensified effort in the load control area would be balanced with a decrease in effort in other areas. Therefore, the initial costs of this program are assumed to be zero. There are no recurring annual costs with this option.

IABLE 2.3. Currently Proposed Residential MCS Hourly Loads(a)

\begin{tabular}{|c|c|c|c|c|c|}
\hline Hour & $\begin{array}{l}\text { Base Load } \\
\text { (kw) }\end{array}$ & $\begin{array}{l}\text { Controlled } \\
\text { Load (kw) }\end{array}$ & Hour & $\begin{array}{l}\text { Base Load } \\
\quad(k N) \\
\end{array}$ & $\begin{array}{l}\text { Controlled } \\
\text { Load }(\mathrm{kw})\end{array}$ \\
\hline $\begin{array}{r}1 \\
2 \\
3 \\
4 \\
5 \\
6 \\
7 \\
8 \\
9 \\
10 \\
11 \\
12\end{array}$ & $\begin{array}{l}0.431 \\
0.423 \\
0.444 \\
0.468 \\
0.507 \\
0.570 \\
0.822 \\
1.0 \\
0.899 \\
0.814 \\
0.759 \\
0.708\end{array}$ & $\begin{array}{l}0.237 \\
0.233 \\
0.244 \\
0.257 \\
0.279 \\
0.314 \\
0.452 \\
0.550 \\
0.494 \\
0.448 \\
0.417 \\
0.389\end{array}$ & $\begin{array}{l}13 \\
14 \\
15 \\
16 \\
17 \\
18 \\
19 \\
20 \\
21 \\
22 \\
23 \\
24\end{array}$ & $\begin{array}{l}0.669 \\
0.617 \\
0.562 \\
0.568 \\
0.635 \\
0.714 \\
0.684 \\
0.626 \\
0.642 \\
0.605 \\
0.487 \\
0.424\end{array}$ & $\begin{array}{l}0.369 \\
0.339 \\
0.309 \\
0.312 \\
0.349 \\
0.393 \\
0.376 \\
0.344 \\
0.353 \\
0.333 \\
0.268 \\
0.233\end{array}$ \\
\hline
\end{tabular}

(a) Normalized to peak hour load; conversion factor $=3.586 \mathrm{~kW}$. 


\subsection{ENHANCED RESIDENTIAL MOOEL CONSERVATION STANDARDS}

End use targeted: Space heating in new residential buildings

Description: Upgrade of weatherization of new residential buildings with the installation of a set of weatherization measures identified by the NWPPC (1986, Table 5-26).

Base load data source: PP\&L Project for central electric furnaces

Controlled load data source: NWPPC (1986)

Savings: $68 \% \times$ average hour load

Peak hour load: $3.586 \mathrm{~kW}$

Cost: Cost for implementing the program (above the current MCS program) would be $\$ 1715$ per structure (NWPPC 1986, Table 5-23). No significant yearly cost after the first year would be incurred.

TABLE 2.4. Enhanced Residential MCS Hourly Loads(a)

\begin{tabular}{|c|c|c|c|c|c|}
\hline Hour & $\begin{array}{l}\text { Base Load } \\
\text { (kH) }\end{array}$ & $\begin{array}{l}\text { Controiled } \\
\text { Load (kW) }\end{array}$ & Hour & $\begin{array}{l}\text { Base Load } \\
\text { (kW) }\end{array}$ & $\begin{array}{l}\text { Controlled } \\
\text { Load (kw) }\end{array}$ \\
\hline $\begin{array}{r}1 \\
2 \\
3 \\
4 \\
5 \\
6 \\
7 \\
8 \\
9 \\
10 \\
11 \\
12\end{array}$ & $\begin{array}{l}0.431 \\
0.423 \\
0.444 \\
0.468 \\
0.507 \\
0.570 \\
0.822 \\
1.0 \\
0.899 \\
0.814 \\
0.759 \\
0.708\end{array}$ & $\begin{array}{l}0.138 \\
0.135 \\
0.142 \\
0.150 \\
0.162 \\
0.182 \\
0.263 \\
0.320 \\
0.288 \\
0.260 \\
0.240 \\
0.227\end{array}$ & $\begin{array}{l}13 \\
14 \\
15 \\
16 \\
17 \\
18 \\
19 \\
20 \\
21 \\
22 \\
23 \\
24\end{array}$ & $\begin{array}{l}0.669 \\
0.617 \\
0.562 \\
0.56 \mathrm{~B} \\
0.635 \\
0.714 \\
0.684 \\
0.626 \\
0.642 \\
0.605 \\
0.487 \\
0.424\end{array}$ & $\begin{array}{l}0.214 \\
0.197 \\
0.180 \\
0.182 \\
0.203 \\
0.228 \\
0.219 \\
0.200 \\
0.205 \\
0.194 \\
0.156 \\
0.136\end{array}$ \\
\hline
\end{tabular}

(a) Normalized to peak hour load; conversion factor $=3.586 \mathrm{~kW}$. 


\subsection{RESIDENTIAL CERAMIC HEAT STORAGE - PRIMARY SYSTEM}

End use targeted: Space heating in new and existing residential buildings Description: Storage of heat produced overnight for use during the following day. Shifts space heating load to the off peak (nighttime) hours.

Base load data source: PP\&L Project for central electric furnaces Controlled load data source: EPRI (1980)

Savings: With a sufficient sizing or number of units the entire heating load of a residence can be shifted to the 8 hours immediately preceding the beginning of the peak load period. The heat can then be distributed as needed throughout the day. Thus, the sum of all base case hourly loads is divided by 8 and distributed evenly between the hours from 10:00 p.m. to 6:00 a.m. .

\section{Peak hour load: $3.374 \mathrm{~kW}$}

Cost: The calculated storage requirements of an average home are assumed to be $45.8 \mathrm{kWh}$, and each storage unit has a capacity of about $6.6 \mathrm{kWh}$ per $\mathrm{kW}$ of charging demand (EPRI 1980). Since units are sold on the basis of their charging demand, units drawing a total of $7 \mathrm{~kW}$ are assumed to be adequate for an average size home. At $\$ 350 / \mathrm{kW}$, the average cost per site would be $\$ 2450$ (deGrasse 1983).

TABLE 2.5. Residential Ceramic Heat Storage Primary System Hourly Loads(a)

\begin{tabular}{|c|c|c|c|c|c|}
\hline Hour & $\begin{array}{l}\text { Base Load } \\
\text { (kw) }\end{array}$ & $\begin{array}{l}\text { Controlled } \\
\text { Load (kW) }\end{array}$ & Hour & $\begin{array}{l}\text { Base Load } \\
(\mathrm{kW})\end{array}$ & $\begin{array}{l}\text { Controlled } \\
\text { Load (kW) }\end{array}$ \\
\hline $\begin{array}{r}1 \\
2 \\
3 \\
4 \\
5 \\
6 \\
7 \\
8 \\
9 \\
10 \\
11 \\
12\end{array}$ & $\begin{array}{l}0.431 \\
0.423 \\
0.444 \\
0.468 \\
0.507 \\
0.570 \\
0.822 \\
1.0 \\
0.899 \\
0.814 \\
0.759 \\
0.708\end{array}$ & $\begin{array}{l}1.886 \\
1.886 \\
1.886 \\
1.886 \\
1.886 \\
1.886 \\
0.0 \\
0.0 \\
0.0 \\
0.0 \\
0.0 \\
0.0\end{array}$ & $\begin{array}{l}13 \\
14 \\
15 \\
16 \\
17 \\
18 \\
19 \\
20 \\
21 \\
22 \\
23 \\
24\end{array}$ & $\begin{array}{l}0.669 \\
0.617 \\
0.562 \\
0.568 \\
0.635 \\
0.714 \\
0.684 \\
0.626 \\
0.642 \\
0.605 \\
0.487 \\
0.424\end{array}$ & $\begin{array}{l}0.0 \\
0.0 \\
0.0 \\
0.0 \\
0.0 \\
0.0 \\
0.0 \\
0.0 \\
0.0 \\
0.0 \\
1.886 \\
1.886\end{array}$ \\
\hline
\end{tabular}

(a) Normalized to peak hour load; conversion factor $=3.374 \mathrm{~kW}$. 


\subsection{RESIDENTIAL CERAMIC HEAT STORAGE - BACK-UP SYSTEM}

End use targeted: Space heating in new and existing residential buildings Description: Storage of heat produced overnight for use during the following day. Shifts 2-hour space heating load to the off peak (nighttime) hours.

Base load data source: PP\&L Project for central electric furnaces

Controlled load data source: EPRI (1980)

Savings: As a back-up system, this measure was assumed to only be required to satisfy the demand of 2 peak hours. The 2-hour space heating load of the peak hours is shifted to the 8 hours immediately preceding the beginning of the peak load period. The heat is then distributed as needed throughout the day.

\section{Peak hour load: $3.374 \mathrm{~kW}$}

Cost: It was assumed that $26 \mathrm{kWh}$ would be the maximum heat storage requirement in any 2-hour period (the average undiversified maximum hourly demand from the PP\&L database is $12.9 \mathrm{~kW}$ ) and each storage unit has a capacity of about $6.6 \mathrm{kWh}$ per $\mathrm{kW}$ of charging demand (EPRI 1980). Since units are sold on the basis of their charging demand, units drawing a total of $4 \mathrm{~kW}$ are assumed to be adequate for an average size home. At $\$ 350 / \mathrm{kW}$, the average cost per site would be $\$ 1400$ (deGrasse 1983).

IABLE 2.6. Residential Ceramic Heat Storage Back-up System Hourly Loads(a)

\begin{tabular}{|c|c|c|c|c|c|}
\hline Hour & $\begin{array}{l}\text { Base Load } \\
\text { (kW) }\end{array}$ & $\begin{array}{l}\text { Controlled } \\
\text { Load (kW) }\end{array}$ & Hour & $\begin{array}{l}\text { Base Load } \\
\frac{(k W)}{}\end{array}$ & $\begin{array}{l}\text { Controlled } \\
\text { Load (kW) }\end{array}$ \\
\hline $\begin{array}{r}1 \\
2 \\
3 \\
4 \\
5 \\
6 \\
7 \\
8 \\
9 \\
10 \\
11 \\
12\end{array}$ & $\begin{array}{l}0.431 \\
0.423 \\
0.444 \\
0.468 \\
0.507 \\
0.570 \\
0.822 \\
1.0 \\
0.899 \\
0.814 \\
0.759 \\
0.708\end{array}$ & $\begin{array}{l}0.771 \\
0.764 \\
0.784 \\
0.808 \\
0.848 \\
0.910 \\
0.822 \\
0.0 \\
0.0 \\
0.814 \\
0.759 \\
0.708\end{array}$ & $\begin{array}{l}13 \\
14 \\
15 \\
16 \\
17 \\
18 \\
19 \\
20 \\
21 \\
22 \\
23 \\
24\end{array}$ & $\begin{array}{l}0.669 \\
0.617 \\
0.562 \\
0.568 \\
0.635 \\
0.714 \\
0.684 \\
0.626 \\
0.642 \\
0.605 \\
0.487 \\
0.424\end{array}$ & $\begin{array}{l}0.669 \\
0.617 \\
0.562 \\
0.568 \\
0.639 \\
0.714 \\
0.684 \\
0.626 \\
0.642 \\
0.605 \\
0.828 \\
0.764\end{array}$ \\
\hline
\end{tabular}

(a) Normalized to peak hour load; conversion factor $=3.374 \mathrm{~kW}$. 


\subsection{RESIDENTIAL DIRECT SPACE HEAT CONTROL}

End use targeted: Space heating in new and existing residential buildings Description: Dispatcher controlled radio signals activate on/off remote control unit affixed to the heating system

Base load data source: PP\&L Project for central electric furnaces Controlled load data source: NWPPC (1986)

Savings: An active system turns off a heating system for 7.5 minutes of each 30 minute interval during the period of peak load on the point of delivery (POD) system. The controlled load shape is obtained by reducing power by $25 \%$ (controlling heating 15 minutes per hour) during the peak heating hours between 6:00 a.m. and 9:00 a.m. Payback is needed during noncontrolled periods to compensate for lower heat delivery rates during the direct control period. This compensation is assumed to be a $60 \%$ increase of the heating load during the hour preceding the peak period of the control period. This payback takes place in the hours directly following the controlled period. The payback follows a schedule of $20 \%$ of the controlled loss in the first succeeding hour and $10 \%$ in the second. This schedule assumes a $2.5 \%$ loss of consumption that occurs due to an unavoidable lower level of consumption during the control period.

Peak hour load: $3.374 \mathrm{~kW}$

Cost: The cost of installing the controller would be $\$ 150$ per site. The annual maintenance cost would be $\$ 0.40$ per site.

TABLE 2.7. Residentia] Direct Space Heat Control Hourly Loads(a)

\begin{tabular}{cccccc} 
Hour & $\begin{array}{c}\text { Base Load } \\
(\mathrm{kW})\end{array}$ & $\begin{array}{c}\text { Control led } \\
\text { Load (kW) }\end{array}$ & Hour & $\begin{array}{c}\text { Base Load } \\
(\mathrm{kW})\end{array}$ & $\begin{array}{c}\text { Controlled } \\
\text { Load }(\mathrm{kW})\end{array}$ \\
\hline 1 & 0.431 & 0.431 & 13 & 0.669 & 0.669 \\
2 & 0.423 & 0.423 & 14 & 0.617 & 0.617 \\
3 & 0.444 & 0.444 & 15 & 0.562 & 0.562 \\
4 & 0.468 & 0.468 & 16 & 0.568 & 0.568 \\
5 & 0.507 & 0.507 & 17 & 0.635 & 0.639 \\
6 & 0.570 & 0.978 & 18 & 0.714 & 0.714 \\
7 & 0.822 & 0.617 & 19 & 0.684 & 0.684 \\
8 & 1.0 & 0.75 & 20 & 0.626 & 0.626 \\
9 & 0.899 & 0.674 & 21 & 0.642 & 0.642 \\
10 & 0.814 & 0.951 & 22 & 0.605 & 0.605 \\
11 & 0.759 & 0.827 & 23 & 0.487 & 0.487 \\
12 & 0.708 & 0.776 & 24 & 0.424 & 0.424
\end{tabular}

(a) Normalized to peak hour load; conversion factor $=3.374 \mathrm{~kW}$. 


\section{B RESIDENTIAL GAS BACK-UP PROGRAM FOR ELECTRIC HEAT PUMPS}

End use targeted: Space heating in new and existing residential buildings Description: Gas fueled back-up heating system to be used in-lieu of an electric resistance system when temperatures are too extreme for efficient heat pump use

Base load data source: PP\&L Project for electric heat pump system Controlled load data source: NWPPC (1986)

Savings: This system allows for a gas heating system's use during the peak demand hours and the use of an efficient heat pump during moderate winter weather and during off-peak hours

Peak hour load: $3.557 \mathrm{~kW}$

Cost: The installed cost for a low efficiency gas furnace is approximately $\$ 1500$. No additional cost was assumed for connection to the gas mains since utilities do not charge for the first 80 feet of line and no cost was assumed for the control interface between the gas furnace and the heat pump. However, credit was not taken for the savings resulting from the elimination of the resistance heating unit. It is assumed that these costs are mutually compensatory. These cost estimates are based on information provided by the Cascade Natural Gas Corporation.

IABLE 2.8. Residential Gas Back-up for an Electric Heat Pump Hourly Loads(a)

\begin{tabular}{|c|c|c|c|c|c|}
\hline Hour & $\begin{array}{l}\text { Base Load } \\
(\mathrm{kW})\end{array}$ & $\begin{array}{l}\text { Control led } \\
\text { Load (kW) }\end{array}$ & Hour & $\begin{array}{l}\text { Base Load } \\
(\mathrm{kW})\end{array}$ & $\begin{array}{l}\text { Controlled } \\
\text { Load (kW) }\end{array}$ \\
\hline $\begin{array}{r}1 \\
2 \\
3 \\
4 \\
5 \\
6 \\
7 \\
8 \\
9 \\
10 \\
11 \\
12\end{array}$ & $\begin{array}{l}0.696 \\
0.697 \\
0.717 \\
0.778 \\
0.773 \\
0.829 \\
1.0 \\
0.986 \\
0.851 \\
0.839 \\
0.688 \\
0.572\end{array}$ & $\begin{array}{l}0.696 \\
0.697 \\
0.717 \\
0.778 \\
0.773 \\
0.829 \\
0.0 \\
0.0 \\
0.0 \\
0.839 \\
0.688 \\
0.572\end{array}$ & $\begin{array}{l}13 \\
14 \\
15 \\
16 \\
17 \\
18 \\
19 \\
20 \\
21 \\
22 \\
23 \\
24\end{array}$ & $\begin{array}{l}0.465 \\
0.478 \\
0.452 \\
0.380 \\
0.492 \\
0.539 \\
0.600 \\
0.708 \\
0.713 \\
0.693 \\
0.769 \\
0.684\end{array}$ & $\begin{array}{l}0.465 \\
0.478 \\
0.452 \\
0.380 \\
0.492 \\
0.539 \\
0.600 \\
0.708 \\
0.713 \\
0.693 \\
0.769 \\
0.684\end{array}$ \\
\hline
\end{tabular}

(a) Normalized to peak hour load; conversion factor $=3.557 \mathrm{~kW}$. 


\subsection{RESIDENTIAL DIRECT WATER HEATER CONTROL}

End use targeted: Conventional electric water heater

Description: Direct control of electric water heaters by on $/ 0$ ff radio signals sent to a receiver on the residence's water heater. A POD power dispatcher controls the signal. The system is designed so that a residence's water heater is turned off during the POD peak period.

Base load data source: PP\&L Project

Controlled load data source: NWPPC (1986)

Savings: Controlled load is assumed to operate between 6:00 and 9:00 AM. It is also assumed that water heating energy not received during control periods is paid back evenly across the 3 hours following the peak period (i.e., the sum of the losses divided by 3 and added to the normat water heating load for those hours).

Peak hour load: $1.631 \mathrm{~kW}$

Cost: The cost of installing the controller is $\$ 150$ per site and the annual maintenance cost is $\$ 0.40$ per site.

IABLE 2.9. Residential Direct Water Heater Control Hourly Loads(a)

\begin{tabular}{|c|c|c|c|c|c|}
\hline Hour & $\begin{array}{l}\text { Base Load } \\
(\mathrm{kN})\end{array}$ & $\begin{array}{l}\text { Controlled } \\
\text { Load (kW) }\end{array}$ & Hour & $\begin{array}{l}\text { Base Load } \\
(\mathrm{kN})\end{array}$ & $\begin{array}{l}\text { Controlled } \\
\text { Load (kH) }\end{array}$ \\
\hline $\begin{array}{r}1 \\
2 \\
3 \\
4 \\
5 \\
6 \\
7 \\
8 \\
9 \\
10 \\
11 \\
12\end{array}$ & $\begin{array}{l}0.18 \\
0.152 \\
0.164 \\
0.2 \\
0.208 \\
0.316 \\
0.7 \\
1.0 \\
0.916 \\
0.812 \\
0.72 \\
0.692\end{array}$ & $\begin{array}{l}0.18 \\
0.152 \\
0.164 \\
0.2 \\
0.208 \\
0.316 \\
0.0 \\
0.0 \\
0.0 \\
1.684 \\
1.592 \\
1.564\end{array}$ & $\begin{array}{l}13 \\
14 \\
15 \\
16 \\
17 \\
18 \\
19 \\
20 \\
21 \\
22 \\
23 \\
24\end{array}$ & $\begin{array}{l}0.648 \\
0.536 \\
0.448 \\
0.44 \\
0.464 \\
0.64 \\
0.74 \\
0.784 \\
0.732 \\
0.624 \\
0.424 \\
0.12\end{array}$ & $\begin{array}{l}0.648 \\
0.536 \\
0.448 \\
0.44 \\
0.464 \\
0.64 \\
0.74 \\
0.784 \\
0.732 \\
0.624 \\
0.424 \\
0.12\end{array}$ \\
\hline
\end{tabular}

(a) Normalized to peak hour load; conversion factor $=1.631 \mathrm{kH}$. 


\subsection{RESIDENTIAL DUAL WATER HEATER CONTROL}

End use targeted: Conventional electric water heater

Description: Additional water heater installed and direct control of electric water heaters by on/off radio signals sent to a receiver on the residence's water heater. A POD power dispatcher controls the signal. The system is designed so that a residence's water heaters are turned off during the POD peak period.

Base load data source: PP\&L Project

Controlled load data source: NWPPC (1986)

Savings: Controlled load is assumed to operate between 6:00 a.m. and noon. It is assumed that because of sufficient hot water storage capacity, which has been doubled by the addition of a second water heating unit, no consumption is lost. The payback of the water heat load lost during the control period is assumed to occur evenly across the 3 hours preceding and the 3 hours following the peak period (i.e., the sum of the losses divided by 6 and added to the normal water heating load for those hours).

Peak hour load: $1.631 \mathrm{~kW}$

Cost: The cost of installing the additional water heater and the controller is $\$ 400$ per site. The annual maintenance cost is $\$ 0.40$ per site. The cost figures are derived from PNL research and manufacturer data on water heaters.

IABLE 2.10. Residential Dual Water Heater Control Hourly Loads(a)

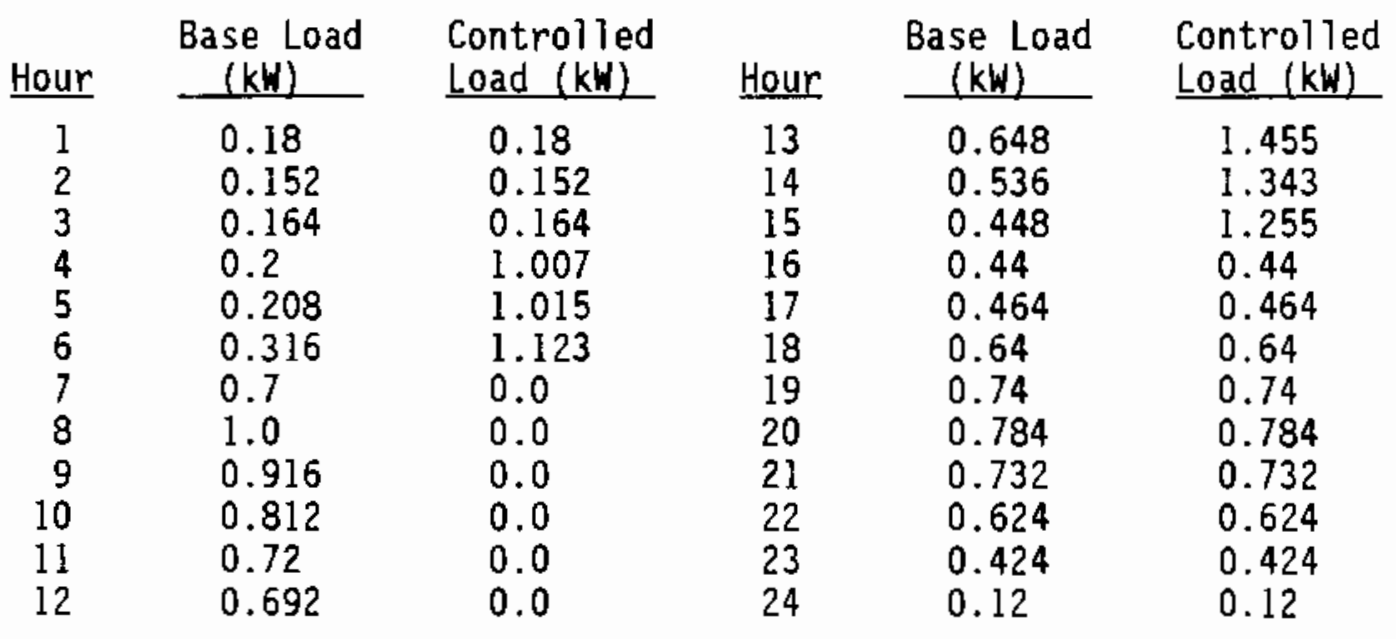

(a) Normalized to peak hour load; conversion factor $=1.631 \mathrm{~kW}$. 


\subsection{RESIDENTIAL SMART WHOLE HOUSE LOAD LIMITERS}

End use targeted: Space and water heat, other major electricity end uses Description: Devices that regulate either a household's instantaneous electrical demand (0 to 5 minute period) or average demand (over a 15 to 60 minute period) by imposing limitations on appliance use in a priority or sequential order. Smart systems are designed to keep the total household load at or below a demand set point selected by the home owner in an appliance regulation scheme.

Base load data source: PP\&L Project

Controlled load data source: NWPPC (1986)

Savings: It is assumed that the total household hourly load is restricted to a maximum of $80 \%$ of the uncontrolled peak hour load for all hours of the day. The energy which is not consumed during the controlled (i.e., the peak) hours is assumed to be redistributed amongst the nonpeak hours so that total net energy savings are effectively zero.

Peak hour load: $6.353 \mathrm{~kW}$

cost: The technology is too new to establish a representative cost. However, an energy management system that is less sophisticated costs approximately $\$ 2500$ (EPRI 1986). The annual cost is assumed to be zero.

TABLE 2.11. Residential Smart Whole House Load Limiters(a)

\begin{tabular}{|c|c|c|c|c|c|}
\hline Hour & $\begin{array}{l}\text { Base Load } \\
(\mathrm{kW})\end{array}$ & $\begin{array}{l}\text { Controlled } \\
\text { Load }(\mathrm{kW})\end{array}$ & Hour & $\begin{array}{l}\text { Base Load } \\
(\mathrm{KH}) \\
\end{array}$ & $\begin{array}{l}\text { Controlled } \\
\text { Load (kW) }\end{array}$ \\
\hline $\begin{array}{r}1 \\
2 \\
3 \\
4 \\
5 \\
6 \\
7 \\
8 \\
9 \\
10 \\
11 \\
12\end{array}$ & $\begin{array}{l}0.363 \\
0.358 \\
0.379 \\
0.415 \\
0.449 \\
0.523 \\
0.803 \\
1.0 \\
0.919 \\
0.839 \\
0.780 \\
0.743\end{array}$ & $\begin{array}{l}0.363 \\
0.358 \\
0.379 \\
0.415 \\
0.449 \\
0.8 \\
0.8 \\
0.8 \\
0.8 \\
0.8 \\
0.8 \\
0.8\end{array}$ & $\begin{array}{l}13 \\
14 \\
15 \\
16 \\
17 \\
18 \\
19 \\
20 \\
21 \\
22 \\
23 \\
24\end{array}$ & $\begin{array}{l}0.711 \\
0.641 \\
0.585 \\
0.579 \\
0.664 \\
0.804 \\
0.807 \\
0.766 \\
0.756 \\
0.679 \\
0.510 \\
0.338\end{array}$ & $\begin{array}{l}0.717 \\
0.641 \\
0.585 \\
0.579 \\
0.674 \\
0.8 \\
0.8 \\
0.766 \\
0.756 \\
0.679 \\
0.510 \\
0.338\end{array}$ \\
\hline
\end{tabular}

(a) Normalized to peak hour load; conversion factor $=6.353 \mathrm{~kW}$. 


\subsection{COMMERCIAL SECTOR}

The commercial sector is composed of diverse building types used for many different purposes and, consequently, uses electricity in ways that are difficult to characterize. The sector's diversity, along with the paucity of detailed energy-use data, require that load shapes be put together by building type. Unfortunately, there are a limited number of ELCAP-metered buildings in each building type so that end-use load shapes are calculated from a relatively narrow database.

Lighting is a major end use of the total commercial sector load (NWPPC 1986). Recent advancements in the design of lighting systems improve the energy efficiency of lighting. A typical lighting system has the following three basic parts each of which contributes to the energy use of the system: the ballast, the fluorescent tube or lamp, and the fixture. Most commercial lighting systems presently in use already have fluorescent fixtures so fixture replacement is not discussed in this report. The lighting contributions to the total load were estimated by dividing the NWPPC (1986) estimate of yearly lighting energy consumption by annual total electricity consumption. (a)

For the anaiyses of the commercial sector, the controlled load was obtained by first determining each building type's normalized average hourly load (i.e., the sum of all normalized base case hourly loads divided by the 24 hours in a day). Next, a percent energy use savings figure was calculated by multiplying a percent estimate of the building type's total load that is the lighting load (NWPPC 1986) by the expected savings of the C\&LM option. The percent savings figure was then multiplied by the normalized average hourly load to obtain an average per hour savings figure (i.e., percent

(a) Obtained from the NWPPC via a telephone conversation on October 1, 1986. The NWPPC, in turn, obtained the data from the NWPPC 1986 commercial sector medium-high price driven forecast for the year 1985. The lighting and total electricity use data provided for offices, dry-goods/ retail stores, and restaurants in trillion of BTU's are respectively: $10,33.82 ; 7.81,26.93 ; 1.89,8.45$. 
savings $x$ average hour load $=$ average hour load savings). Finally, the controlled load was obtained by subtracting that average load savings from each hour of the day of the normalized base case. 


\subsection{COMMERCIAL LIGHTING - LIGHT REPLACEMENT PROGRAM}

End use targeted: Lighting for three commercial building type categories: offices, dry-goods/retail stores, and restaurants.

Description: Replacement of fluorescent lighting bulbs

Base load data source: BPA End-Use Research Section

Controlled load data source: Moe et a1. (1986)

Savings: It should be noted again that the base-load data represents a normalized total (i.e., all end uses combined) hourly load for a representative building of each commercial building type. For office buildings, a $15 \%$ savings from a lighting load that is $29.6 \%$ of the total load amounts to saving of $4.44 \%$ of the total load. For dry-goods/retail stores, a $15 \%$ savings from a lighting load that is $29 \%$ of the total load amounts to a total load savings of about $4.35 \%$. For restaurants, a $15 \%$ savings from a lighting load that is $22.4 \%$ of the total load amounts to a total load savings of about $3.36 \%$.

Peak hour load: Office buildings $=1.57 \mathrm{~W} / \mathrm{ft}^{2}$, dry-goods $/$ retail stores $=$ $1.48 \mathrm{~W} / \mathrm{ft}^{2}$, restaurants $=1.62 \mathrm{~W} / \mathrm{ft}^{2}$.

Cost: The cost of a new efficient buib is $\$ 2.64$ versus $\$ 1.75$ for a standard bulb. Therefore, the additional cost for a more efficient bulb is $\$ 0.89$ when a burned-out 40 watt bulb is replaced.

IABLE 3.1. Commercial Lighting - Offjce Buildings
Light Replacement Program(a)

\begin{tabular}{|c|c|c|c|c|c|}
\hline Hour & $\begin{array}{l}\text { Base Load } \\
\text { (kW) }\end{array}$ & $\begin{array}{l}\text { Control led } \\
\text { Load }(\mathrm{kW})\end{array}$ & Hour & $\begin{array}{l}\text { Base Load } \\
(\mathrm{kW})\end{array}$ & $\begin{array}{l}\text { Controlled } \\
\text { Load }(\mathrm{kW})\end{array}$ \\
\hline $\begin{array}{r}1 \\
2 \\
3 \\
4 \\
5 \\
6 \\
7 \\
8 \\
9 \\
10 \\
11 \\
12\end{array}$ & $\begin{array}{l}0.409 \\
0.396 \\
0.380 \\
0.372 \\
0.380 \\
0.392 \\
0.422 \\
0.547 \\
0.806 \\
1.952 \\
0.963 \\
0.977\end{array}$ & $\begin{array}{l}0.347 \\
0.336 \\
0.323 \\
0.316 \\
0.323 \\
0.334 \\
0.358 \\
0.465 \\
0.685 \\
0.809 \\
0.819 \\
0.830\end{array}$ & $\begin{array}{l}13 \\
14 \\
15 \\
16 \\
17 \\
18 \\
19 \\
20 \\
21 \\
22 \\
23 \\
24\end{array}$ & $\begin{array}{l}0.978 \\
0.977 \\
0.987 \\
1.000 \\
0.989 \\
0.888 \\
0.771 \\
0.676 \\
0.620 \\
0.551 \\
0.484 \\
0.449\end{array}$ & $\begin{array}{l}0.831 \\
0.831 \\
0.839 \\
0.850 \\
0.841 \\
0.755 \\
0.656 \\
0.575 \\
0.527 \\
0.468 \\
0.412 \\
0.382\end{array}$ \\
\hline
\end{tabular}

(a) Normalized to peak hour load; conversion factor $=1.57 \mathrm{~W} / \mathrm{ft}^{2}$. 

TABLE 3.2. Commercial Lighting - Dry-Goods/Retail Stores
Light Replacement Program(a)

\begin{tabular}{|c|c|c|c|c|c|}
\hline Hour & $\begin{array}{c}\text { Base Load } \\
\text { (kW) }\end{array}$ & $\begin{array}{l}\text { Controlled } \\
\text { Load (kW) }\end{array}$ & Hour & $\begin{array}{c}\text { Base Load } \\
(\mathbf{k W})\end{array}$ & $\begin{array}{l}\text { Controlled } \\
\text { Load (kW) }\end{array}$ \\
\hline $\begin{array}{r}1 \\
2 \\
3 \\
4 \\
5 \\
6 \\
7 \\
8 \\
9 \\
10 \\
11 \\
12\end{array}$ & $\begin{array}{l}0.241 \\
0.237 \\
0.233 \\
0.275 \\
0.276 \\
0.285 \\
0.299 \\
0.426 \\
0.585 \\
0.769 \\
0.864 \\
0.987\end{array}$ & $\begin{array}{l}0.205 \\
0.202 \\
0.198 \\
0.234 \\
0.235 \\
0.242 \\
0.254 \\
0.362 \\
0.497 \\
0.653 \\
0.734 \\
0.839\end{array}$ & $\begin{array}{l}13 \\
14 \\
15 \\
16 \\
17 \\
18 \\
19 \\
20 \\
21 \\
22 \\
23 \\
24\end{array}$ & $\begin{array}{l}0.996 \\
0.998 \\
0.999 \\
1.000 \\
0.979 \\
0.791 \\
0.705 \\
0.677 \\
0.564 \\
0.311 \\
0.257 \\
0.246\end{array}$ & $\begin{array}{l}0.847 \\
0.848 \\
0.850 \\
0.850 \\
0.832 \\
0.672 \\
0.599 \\
0.576 \\
0.479 \\
0.264 \\
0.218 \\
0.209\end{array}$ \\
\hline
\end{tabular}

(a) Normalized to peak hour load; conversion factor $=1.48 \mathrm{~W} / \mathrm{ft}^{2}$.

IABLE 3.3. Commercial Lighting - Restaurants Light Replacement Program(a)

\begin{tabular}{|c|c|c|c|c|c|}
\hline Hour & $\begin{array}{l}\text { Base Load } \\
\text { (kWW }\end{array}$ & $\begin{array}{l}\text { Controlled } \\
\text { Load (KW) }\end{array}$ & Hour & $\begin{array}{l}\text { Base Load } \\
\text { (kW) }\end{array}$ & $\begin{array}{l}\text { Controlled } \\
\text { Load }(\mathbf{k W})\end{array}$ \\
\hline $\begin{array}{r}1 \\
2 \\
3 \\
4 \\
5 \\
6 \\
7 \\
8 \\
9 \\
10 \\
11 \\
12\end{array}$ & $\begin{array}{l}0.439 \\
0.454 \\
0.401 \\
0.267 \\
0.220 \\
0.264 \\
0.378 \\
0.505 \\
0.612 \\
0.634 \\
0.717 \\
0.888\end{array}$ & $\begin{array}{l}0.373 \\
0.386 \\
0.341 \\
0.227 \\
0.187 \\
0.224 \\
0.321 \\
0.430 \\
0.520 \\
0.539 \\
0.609 \\
0.755\end{array}$ & $\begin{array}{l}13 \\
14 \\
15 \\
16 \\
17 \\
18 \\
19 \\
20 \\
21 \\
22 \\
23 \\
24\end{array}$ & $\begin{array}{l}0.902 \\
0.899 \\
0.918 \\
0.932 \\
0.949 \\
1.000 \\
0.901 \\
0.848 \\
0.719 \\
0.655 \\
0.585 \\
0.478\end{array}$ & $\begin{array}{l}0.767 \\
0.764 \\
0.780 \\
0.792 \\
0.807 \\
0.850 \\
0.766 \\
0.721 \\
0.611 \\
0.557 \\
0.497 \\
0.406\end{array}$ \\
\hline
\end{tabular}

(a) Normalized to peak hour load; conversion factor $=1.62 \mathrm{~W} / \mathrm{ft}^{2}$. 


\subsection{COMMERCIAL LIGHTING - REPLACEMENT OF BALLASTS AND LAMPS}

End use targeted: Lighting for three comercial building type categories: offices, dry-goods/retail stores, and restaurants.

Description: Replacement of fluorescent lighting ballasts and lamps

Base load data source: BPA End-Use Research Section

Controlled load data source: Moe (1986)

Savings: The estimated savings from the lighting load of commercial buildings due to the replacement of both ballasts and lamps is $35 \%$. For office buildings, a $35 \%$ savings from a lighting load that is $29.6 \%$ of the total load amounts to a total load savings of about $10.36 \%$. For dry-goods/retail stores, a $35 \%$ savings from a lighting load that is $29.0 \%$ of the total load amounts to a total load savings of about $10.15 \%$. For restaurants, a $35 \%$ savings from a lighting load that is $\mathbf{2 2 . 4 \%}$ of the total load amounts to a total load savings of about $7.84 \%$.

Peak hour load: Office buildings $=1.57 \mathrm{~W} / \mathrm{ft}^{2}$, dry-goods $/$ retail stores $=$ $1.48 \mathrm{~W} / \mathrm{ft}^{2}$, restaurants $=1.62 \mathrm{~W} / \mathrm{ft}^{2}$

Cost: The cost of a new efficient ballast is $\$ 28$ versus $\$ 14$ for a standard ballast. Therefore, the additional cost for the more efficient ballast is $\$ 14$ when a failed ballast is replaced. The additional cost for the more efficient bulb is $\$ 0.89$ ( $\$ 2.64$ versus $\$ 1.75$ ) when a burned-out 40 watt bulb is replaced (Moe 1986). 

TABLE 3.4. Commercial Lighting - Office Buildings
Replacement of Ballasts and Lamps $(a)$

\begin{tabular}{|c|c|c|c|c|c|}
\hline Hour & $\begin{array}{l}\text { Base Load } \\
\text { (kW) }\end{array}$ & $\begin{array}{l}\text { Control led } \\
\text { Load (kW) }\end{array}$ & Hour & $\begin{array}{l}\text { Base Load } \\
\quad(k W)\end{array}$ & $\begin{array}{l}\text { Controlled } \\
\text { Load }(\mathrm{kW})\end{array}$ \\
\hline $\begin{array}{r}1 \\
2 \\
3 \\
4 \\
5 \\
6 \\
7 \\
8 \\
9 \\
10 \\
11 \\
12\end{array}$ & $\begin{array}{l}0.409 \\
0.396 \\
0.380 \\
0.372 \\
0.380 \\
0.392 \\
0.422 \\
0.547 \\
0.806 \\
0.952 \\
0.963 \\
0.977\end{array}$ & $\begin{array}{l}0.266 \\
0.257 \\
0.247 \\
0.241 \\
0.247 \\
0.255 \\
0.274 \\
0.356 \\
0.524 \\
0.619 \\
0.626 \\
0.635\end{array}$ & $\begin{array}{l}13 \\
14 \\
15 \\
16 \\
17 \\
18 \\
19 \\
20 \\
21 \\
22 \\
23 \\
24\end{array}$ & $\begin{array}{l}0.978 \\
0.977 \\
0.987 \\
1.000 \\
0.989 \\
0.888 \\
0.771 \\
0.676 \\
0.620 \\
0.551 \\
0.484 \\
0.449\end{array}$ & $\begin{array}{l}0.636 \\
0.635 \\
0.642 \\
0.650 \\
0.643 \\
0.578 \\
0.501 \\
0.440 \\
0.403 \\
0.358 \\
0.315 \\
0.292\end{array}$ \\
\hline
\end{tabular}

(a) Normalized to peak hour load; conversion factor $=1.57 \mathrm{~W} / \mathrm{ft}^{2}$.

IABLE 3.5. Commercial Lighting - Dry-Goods/Retail Stores Replacement of Ballasts and Lamps(a)

$\begin{array}{cccccc}\text { Hour } & \begin{array}{c}\text { Base Load } \\ (\mathbf{k W})\end{array} & \begin{array}{c}\text { Controlled } \\ \text { Load }(\mathrm{kW})\end{array} & \frac{\text { Hour }}{1} & \begin{array}{c}\text { Base Load } \\ (\mathbf{k W})\end{array} & \begin{array}{c}\text { Controlled } \\ \text { Load (kW) }\end{array} \\ 1 & 0.241 & 0.156 & 13 & 0.996 & 0.647 \\ 3 & 0.237 & 0.154 & 14 & 0.998 & 0.649 \\ 3 & 0.233 & 0.151 & 15 & 0.999 & 0.650 \\ 4 & 0.275 & 0.179 & 16 & 1.000 & 0.650 \\ 5 & 0.276 & 0.180 & 17 & 0.979 & 0.636 \\ 6 & 0.285 & 0.185 & 18 & 0.791 & 0.514 \\ 7 & 0.299 & 0.194 & 19 & 0.705 & 0.458 \\ 8 & 0.426 & 0.277 & 20 & 0.677 & 0.440 \\ 9 & 0.585 & 0.380 & 21 & 0.564 & 0.366 \\ 10 & 0.769 & 0.500 & 22 & 0.311 & 0.202 \\ 11 & 0.864 & 0.562 & 23 & 0.257 & 0.167 \\ 12 & 0.987 & 0.641 & 24 & 0.246 & 0.160\end{array}$

(a) Normalized to peak hour load; conversion factor $=1.48 \mathrm{~W} / \mathrm{ft}^{2}$. 


\begin{tabular}{|c|c|c|c|c|c|}
\hline Hour & $\begin{array}{l}\text { Base Load } \\
(\mathrm{kH}) \\
\end{array}$ & $\begin{array}{l}\text { Controlled } \\
\text { Load }(k w)\end{array}$ & Hour & $\begin{array}{l}\text { Base Load } \\
\frac{(\mathrm{kH})}{}\end{array}$ & $\begin{array}{l}\text { Controlled } \\
\text { Load (kH) }\end{array}$ \\
\hline $\begin{array}{r}1 \\
2 \\
3 \\
4 \\
5 \\
6 \\
7 \\
8 \\
9 \\
10 \\
11 \\
12\end{array}$ & $\begin{array}{l}0.439 \\
0.454 \\
0.401 \\
0.267 \\
0.220 \\
0.264 \\
0.378 \\
0.505 \\
0.612 \\
0.634 \\
0.717 \\
0.888\end{array}$ & $\begin{array}{l}0.285 \\
0.295 \\
0.261 \\
0.174 \\
0.143 \\
0.172 \\
0.246 \\
0.328 \\
0.398 \\
0.412 \\
0.466 \\
0.577\end{array}$ & $\begin{array}{l}13 \\
14 \\
15 \\
16 \\
17 \\
18 \\
19 \\
20 \\
21 \\
22 \\
23 \\
24\end{array}$ & $\begin{array}{l}0.902 \\
0.899 \\
0.918 \\
0.932 \\
0.949 \\
1.000 \\
0.901 \\
0.848 \\
0.719 \\
0.655 \\
0.585 \\
0.478\end{array}$ & $\begin{array}{l}0.586 \\
0.584 \\
0.597 \\
0.606 \\
0.617 \\
0.650 \\
0.586 \\
0.551 \\
0.467 \\
0.426 \\
0.380 \\
0.311\end{array}$ \\
\hline
\end{tabular}

(a) Normalized to peak hour load; conversion factor $=1.62 \mathrm{~W} / \mathrm{ft}^{2}$. 
.

. 


\subsection{AGRICULTURAL IRRIGATION EFFICIENCY PROGRAM}

End use targeted: Electrically driven irrigation systems

Description: Replacement of sprinkler heads with low pressure units thereby reducing the installed horsepower usage or requirements

Base load data source: BPA Division of Power Forecasting

Controlled load data source:

Savings: Current systems operate at approximately $1 \mathrm{~kW}$ per rated installed horsepower. This option allows for a potential reduction of electric energy consumption to a level of 650 watts per rated horsepower of motors already in place. Thus, the base loads are reduced to $65 \%$ of their base values.

Peak hour load: I $\mathrm{kW} /$ rated $\mathrm{hp}$

Cost: This option is to be concentrated in areas where its load control value is most effective in contributing to ATT objectives. This intensified effort in the load control area would be balanced by a decrease in effort in other areas. Thus, the initial cost of this program is assumed to be zero. There are no recurring annual costs.

TABLE 4.1. Agricultural Irrigation - Irrigation Efficiency Program(a)

\begin{tabular}{|c|c|c|c|c|c|}
\hline Hour & $\begin{array}{l}\text { Base Load } \\
\frac{(\mathrm{kW})}{}\end{array}$ & $\begin{array}{l}\text { Controlled } \\
\text { Load (kw) }\end{array}$ & Hour & $\begin{array}{l}\text { Base Load } \\
\qquad \begin{array}{l}(\mathbf{k W})\end{array}\end{array}$ & $\begin{array}{l}\text { Controlled } \\
\text { Load (kW) }\end{array}$ \\
\hline $\begin{array}{r}1 \\
2 \\
3 \\
4 \\
5 \\
6 \\
7 \\
8 \\
9 \\
10 \\
11 \\
12\end{array}$ & $\begin{array}{l}0.948 \\
0.948 \\
0.923 \\
0.923 \\
0.897 \\
0.897 \\
0.897 \\
0.923 \\
0.974 \\
0.974 \\
1.000 \\
1.000\end{array}$ & $\begin{array}{l}0.616 \\
0.616 \\
0.6 \\
0.6 \\
0.583 \\
0.583 \\
0.583 \\
0.6 \\
0.633 \\
0.633 \\
0.65 \\
0.65\end{array}$ & $\begin{array}{l}13 \\
14 \\
15 \\
16 \\
17 \\
18 \\
19 \\
20 \\
21 \\
22 \\
23 \\
24\end{array}$ & $\begin{array}{l}1.0 \\
1.0 \\
0.974 \\
0.974 \\
0.974 \\
0.974 \\
0.974 \\
1.0 \\
1.0 \\
0.974 \\
0.974 \\
0.949\end{array}$ & $\begin{array}{l}0.65 \\
0.65 \\
0.633 \\
0.633 \\
0.633 \\
0.633 \\
0.633 \\
0.65 \\
0.65 \\
0.633 \\
0.633 \\
0.616\end{array}$ \\
\hline
\end{tabular}

(a) Normalized to peak hour load; conversion factor $=1 \mathrm{kH} / \mathrm{hp}$. 
. 


\subsection{INDUSTRIAL MOTOR CAPACITANCE}

End use targeted: Chemical, lumber and metal, and total sector electric motors

Description: Capacitance is inserted to enhance the power factor of motors Base load data source: BPA Division of Power Forecasting and the Tennessee Valley Authority

\section{Controlled load data source:}

Savings: Reduces motor load to $82 \%$ of its base load

Peak hour load: $20.96 \mathrm{kVA} / 20 \mathrm{hp}$

Cost: It was calculated that $6.6534 \mathrm{kVAr}$ of capacitance is needed for correction to a 0.95 power factor. At $\$ 40$ per kVAr, the total cost of the correction is $\$ 266$.

TABLE 5.1. Industrial Motor Capacitance - Chemical, Metals and Lumber(a)

\begin{tabular}{|c|c|c|c|c|c|}
\hline Hour & $\begin{array}{l}\text { Base Load } \\
\text { (kw) }\end{array}$ & $\begin{array}{l}\text { Control1ed } \\
\text { Load (kW) }\end{array}$ & Hour & $\begin{array}{l}\text { Base Load } \\
\text { (kW) }\end{array}$ & $\begin{array}{l}\text { Controlled } \\
\text { Load (kW) }\end{array}$ \\
\hline $\begin{array}{r}1 \\
2 \\
3 \\
4 \\
5 \\
6 \\
7 \\
8 \\
9 \\
10 \\
11 \\
12\end{array}$ & $\begin{array}{l}0.711 \\
0.676 \\
0.673 \\
0.666 \\
0.673 \\
0.725 \\
0.805 \\
0.916 \\
1.000 \\
0.992 \\
0.986 \\
0.954\end{array}$ & $\begin{array}{l}0.583 \\
0.555 \\
0.552 \\
0.546 \\
0.552 \\
0.595 \\
0.660 \\
0.751 \\
0.820 \\
0.814 \\
0.809 \\
0.783\end{array}$ & $\begin{array}{l}13 \\
14 \\
15 \\
16 \\
17 \\
18 \\
19 \\
20 \\
21 \\
22 \\
23 \\
24\end{array}$ & $\begin{array}{l}0.907 \\
0.931 \\
0.919 \\
0.892 \\
0.855 \\
0.842 \\
0.870 \\
0.871 \\
0.864 \\
0.850 \\
0.829 \\
0.790\end{array}$ & $\begin{array}{l}0.744 \\
0.764 \\
0.754 \\
0.732 \\
0.701 \\
0.691 \\
0.714 \\
0.715 \\
0.709 \\
0.697 \\
0.680 \\
0.648\end{array}$ \\
\hline
\end{tabular}

(a) Normalized to peak hour load; conversion factor $=20.96 \mathrm{kVA} / 20 \mathrm{hp}$. 


\begin{tabular}{|c|c|c|c|c|c|}
\hline Hour & $\begin{array}{l}\text { Base Load } \\
\frac{(k \omega)}{}\end{array}$ & $\begin{array}{l}\text { Controlled } \\
\text { Load (kW) }\end{array}$ & Hour & $\begin{array}{l}\text { Base load } \\
(\mathrm{kW})\end{array}$ & $\begin{array}{l}\text { Controlled } \\
\text { Load (kW) }\end{array}$ \\
\hline $\begin{array}{r}1 \\
2 \\
3 \\
4 \\
5 \\
6 \\
7 \\
8 \\
9 \\
10 \\
11 \\
12\end{array}$ & $\begin{array}{l}0.880 \\
0.857 \\
0.833 \\
0.833 \\
0.833 \\
0.857 \\
0.952 \\
1.000 \\
1.000 \\
1.000 \\
0.976 \\
0.952\end{array}$ & $\begin{array}{l}0.723 \\
0.703 \\
0.684 \\
0.684 \\
0.684 \\
0.703 \\
0.781 \\
0.820 \\
0.820 \\
0.820 \\
0.801 \\
0.781\end{array}$ & $\begin{array}{l}13 \\
14 \\
15 \\
16 \\
17 \\
18 \\
19 \\
20 \\
21 \\
22 \\
23 \\
24\end{array}$ & $\begin{array}{l}0.976 \\
1.000 \\
1.000 \\
0.952 \\
0.952 \\
0.952 \\
0.952 \\
0.952 \\
0.952 \\
0.952 \\
0.92 \mathrm{~B} \\
0.928\end{array}$ & $\begin{array}{l}0.801 \\
0.820 \\
0.820 \\
0.781 \\
0.781 \\
0.781 \\
0.781 \\
0.781 \\
0.781 \\
0.781 \\
0.762 \\
0.762\end{array}$ \\
\hline
\end{tabular}

(a) Normalized to peak hour load; conversion factor $=20.96 \mathrm{kVA} / 20 \mathrm{hp}$. 


\subsection{LOAD MANAGEMENT OPTIONS LACKING DATA}

The following discussion relates to ATT options that have been ident $i$ fied but for which there are no readily available information or data that indicate their peak load reduction capabilities in the area of interest. These comments relate to the applicability of the option and/or anticipated level of difficulty in obtaining relevant information.

1. Commercial EMS Program: Unknown value vis-a-vis commercial programs considered in Table 1.2.

2. Enhanced Commercial MCS: It is expected that available assessments of commercial MCS program potential could be adjusted to reflect an enhanced program rather easily.

3. Self-financed Commercial Audits and Measures Installation: Unknown value at present.

4. Commercial TOD Pricing: This option would be likely to involve estimation of price elasticities that could exceed resources of the present study.

5. Industrial TOD Pricing: This option would be likely to involve estimation of price elasticities that could exceed resources of the present study.

6. Residential TOD Pricing: This option would be likely to involve estimation of price elasticities that could exceed resources of the present study.

7. Commercial Heat Storage: Unknown value at present.

8. Commercial Cool Storage: Unknown value at present.

9. Street Lighting Retrofit: There do not appear to be many "large" population or urban centers in the study area, thus it is not expected that this measure would contribute significantly to peak load reduction.

10. Institutional Building Weatherization Program: Cursory review suggests that this is not a large resource in comparison to other weatherization options.

11. Industrial Motor Replacement: The industrial base appears to be limited to a number of wood, pulp, and/or paper mills in the region. It is believed that these types of operations run on a continuous basis, 24 hours a day and probably on a fairly constant basis with motors that may have been acquired when energy costs were lower than at present. 
The study area may contain an industrial motor stock of lower than currently cost-effective efficiency. This resource should be evaluated to determine its place in the priority of options.

12. Industrial Motor Speed Control: Related to Item 11, motors used in certain processes are either "off" or "on" and generally not fitted with control proportional to load. If the energy saving potential of Option 11 were significant, Option 12 should be considered as an associated measure.

13. Irrigation Motor Control: The study area does not appear to contain a significant amount of irrigated agriculture. This measure would be probably only a small incremental value to other irrigation measures enumerated in Chapter 4.0. 


\subsection{EFFICIENCY IMPROVEMENT OF CUSTOMER UTILITY SYSTEMS}

The CSEI studies, conducted by PNL for BPA, showed that several T\&D system improvement measures, including distribution voltage upgrades, conservation voltage regulation (CVR), transformer replacement, reconductoring lines, and capacitor addition, can be cost-effective alternatives to new generating capacity valued at 5 cents/kwh (based on 1985 dollars). The total conservation resource available from efficiency improvements on BPA customer utility systems was estimated to be in the range between 460 and 550 AMW. At the time that analysis was performed, the corresponding total load represented by the utilities studied was the order of 16,000 AMW. The results suggested an average cost-effective conservation resource equal to about $3 \%$ of the total end-use load.

Table 7.1 shows sales (latest available at the time of this report) of the three customer utilities affected by the Shelton-Fairmount Project. Assuming that no substantial change has taken $\mathrm{place}$, a first-order estimate of the value of applying CSEI-type measures in this area would be a conservation resource of approximately 2.5 to 3 average megawatts. This is the resource that would potentially offset new generation needs. As ATT options must be valued at approximately one order of magnitude less than alternates to generation, there appears, even from cursory analysis, little value in CSEI measures as ATT options.

There is, however, an important exception to this conclusion. The cost of a large portion of the conservation derived from applying CVR measures is very low $(0.001$ to $0.1 \mathrm{cent} / \mathrm{kWh})$. Conservation at this level of cost appears to be viable as an ATT option. Similarly, the supply curves PNL

TABLE 7.1. Customer Utility Sales

\begin{tabular}{|c|c|c|c|}
\hline PUD & Sales (MWh) & Year & Average Megawatts \\
\hline Mason County \#1 & 44,008 & 1983 & 5.02 \\
\hline Mason County $\# 3$ & 374,946 & 1984 & 42.80 \\
\hline Clallam County & 357,928 & 1984 & 40.90 \\
\hline
\end{tabular}


generated for other CSEI options show parts of their respective conservation potential costing less than 1 cent/kWh (Tepel et al. 1987; De Steese et al. 1987). In view of this, there appears to be value in considering the CSEI potential of the following options (in order of expected value) applied specifically to the three PUD systems:

1. CVR

2. distribution voltage increase

3. transformer replacement

4. capacitor addition.

The principal value of these analyses will be to establish the value of the best CSEI measures as ATT options and, therefore, for the first time, to create an ability to rank such options in priority against load management measures. An additional value that can result from such system-specific assessments would be the guidance provided on how far PUD-type utilities have gone in applying conservation measures at the distribution-system level. 


\subsection{COGENERATION ALTERNATIVES}

A technique for deferring peak capacity improvements is through encouraging cogeneration. Cogeneration defers or eliminates the need for increasing the size of the T\&D system by providing power from within the grid itself. The use of cogeneration in the area under study depends on both the latent capacity for installation of cogeneration resources and the economic incentives needed to convert that latent capacity into generation resources.

As part of its examination of cogeneration potential BPA has commissioned an assessment of voluntary commercial and industrial cogeneration potential in the Pacific Northwest. That assessment focused on the amount the cogeneration that was likely to be produced in different areas of the Pacific Northwest under different pricing scenarios. The information resulting from that assessment can be used to infer the quantity of industrial cogeneration avajlable in the 01ympic Peninsula (BPA 1987).

One difficulty that plagues that report in its application to virtually any peak reduction analysis is that the areas studied will not match precisely with the areas served by a particular T\&D system. In that case, the area studied included all of the Olympic Peninsula plus Gray's Harbor and Tacoma. The imperfect geographic match is an important technical limitation to the simple application of the report's findings. Table 8.1 provides a selected listing of the technically feasible megawatts available for the entire area.

TABLE 8.1. Selected Technically Feasible quantities of Industrial Cogeneration

\begin{tabular}{lr} 
SIC Code Group & $\begin{array}{r}\text { Cogenerat } \\
\text { Potential }\end{array}$ \\
\cline { 2 - 2 } Food Industry & 222 \\
Wood Industry & 1061 \\
Paper Industry & 4950 \\
Restaurants & 639 \\
Retail Trade & 1573 \\
Office Buildings & 772 \\
Hotel/Motel & 281 \\
Hospitals & 147
\end{tabular}


As can be seen, nearly 10,000 megawatts are available in the overall area studied. Several observations about the total can be made. First, Tacoma is likely to account for much of the office buildings and retail trade. In addition, a considerable part of the hospitals and food industry is likely to be located in Tacoma. Several large wood and paper product plants are located in Gray's Harbor. The wood products industry cogeneration available to BPA is likely to be considerably less than the total shown in Table 8.1.

If, however, only 5\% of the area's cogeneration capacity resided in the study area, nearly 500 megawatts of technically available cogeneration would be possible to draw upon. If a mere $10 \%$ of that could be purchased economically, an as yet not well understood criteria, then 50 megawatts of peak demand could be removed from the forecasted needs. Clearly, cogeneration could play a major role in the analysis of peak load reduction options. 


\subsection{INTERIM RECOMMENDATIONS}

From consideration of information in the preceding chapters and from limited knowledge of both the load type and distribution on the 01ympic Peninsula, the following measures are considered preferred candidates for further analysis in this project:

1. residential heat storage

2. industrial cogeneration

3. residential water heater controls

4. residential space heat control

5. residential heat pump program.

The above choices reflect an expectation that the highest payback will come from measures that effect load control of the residential contribution to the peak load.

As discussed above, other options are of interest even if their potential contribution is expected to be lower than that of the preferred options. In many cases, ranking of these options against the obviously better choices has not been done before. Some of the less-obviously desirable options should be reviewed, at least at a general level, to determine: 1) where they rank on an overall priority basis and 2) that there are no unusual circumstances that give a particular measure an unexpected advantage. For these reasons the general value of the following measures should be established for the study area:

6. residential dual water heater control

7. enhanced residential MCS

8. residential TOD pricing

9. whole-house (Smart) load limiters

10. commercial heat storage

11. commercial light replacement program 
12. commercial ballast or fixture replacement program

13. enhanced commercial MCS

14. industrial motor replacement

15. industrial motor speed control

16. capacitors for industrial motors

17. industrial TOD pricing.

Finally, and for similar reasons, the following CSEI measures should be evaluated at a level of detail sufficient to establish their place in the PLM priority 1 ist:

18. CVR

19. distribution voltage increase

20. distribution transformer replacement

21. shunt capacitor addition. 


\subsection{REFERENCES}

Bonneville Power Administrator (BPA). 1987. Assessment of Commercial and Industrial Cogeneration Potential in the Pacific Northwest. Prepared by ADM Associates, Inc. for the Bonneville Power Administration, Portland, Oregon.

deGrasse, R. 1983. "Commercialization of Electric Storage Heating". In ETectric Power Research Institute. Opportunities in Thermal Storage Research and Development. EPRI EM-3159-SR, Electric Power Research Institute, Palo Alto, California.

DeSteese, J. G., S. B. Merrick, R. C. Tepel, and J. W. Ca1loway. 1987. Assessment of Conservation Voltage Reduction Applicable in the BPA Service Area. DOE/BP-14031-1. Prepared by Pacific Northwest Laboratory for the U.S. Department of Energy, Bonneville Power Administration, Portland, Oregon.

Electric Power Research Institute (EPRI). 1980. Evaluation of LoadManagement Systems and Devices. EPRI EM-1423, Electric Power Research Institute, Palo Alto, California.

Electric Power Research Institute (EPRI). 1986. Residential Load Control and Monitoring Equipment a Summary of Costs and Capabilities. Electric Power Research Institute, Palo Alto, California.

Engl in, J. E., M. S. Klan, A. J. Lyke, J. J. Tawil, J. G. De Steese and R. C. Tepel. 1987. Load Management Alternatives to Transmission and Distribution Construction: Toledo-Wren Case Study. PNL-5931, Pacific Northwest Laboratory, Richland, Washington.

Moe, R., B. Harrer, M. A. Kellogg, A. Lyke, K. Imhoff, and 2. Fisher. 1986. The Electric Energy Savings from New Technologies. PNL-5665, Pacific Northwest Laboratory, Richland, Washington.

Northwest Power Planning Council (NWPPC). 1986. Northwest Conservation and Electric Power Plan. Northwest Power Planning Council, Portland, Oregon.

Tepel, R. C., J. W. Calloway, and J. G. De Steese. 1987. Customer System Efficiency Improvement Assessment: Supply Curves for Transmission and Distribution Conservation Options. PNL-6076, Pacific Northwest Laboratory, Richland, Washington. 


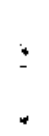


PNL -7173

UC-920

\section{DISTRIBUTION}

No. of

Copies

30 A. E. Vinnard

RPED

Bonneville Power Administration

P.0. Box 3621

Portland, OR 97208

2 DOE Technical Information Center

\section{ONSITE}

I DOE Richland Operations Office

C. E. Collantes
No. of

Copies

23 Pacjfic Northwest Laboratory

C. A. Counts

J. G. De Steese (4)

J. E. Engl in (10)

M. A. Kellogg

R. W. Schultz Publishing Coordination MH Technical Report Files (5) 
$\div$ 